\title{
Use of betapropiolactone to disinfect fresh tissue without impairing antigenicity: method applicable to human immunodeficiency virus (HIV) positive tissue
}

\author{
A J CHAPLIN, A HERYET, LINDA N HOLDSWORTH, * R P EGLIN,* P R MILLARD \\ Department of Histopathology, and the *Department of Virology, Public Health Laboratory, John Radcliffe \\ Hospital, Oxford
}

SUMMARY A method for inactivating viruses in tissues is reported that does not impair the antigenicity of the Coxsackie virus or of some common tissue antigens, a common problem with standard tissue fixation methods. Tissues can be placed briefly in Betapropiolactone before cryostat sectioning without any adverse effect on preservation or antigen expression.

It is suggested that use of Betapropiolactone is applicable to tissues harbouring or exposed to the human immunodeficiency virus (HIV). As betapropiolactone has been reported to be carcinogenic in rodents any potential danger can be avoided by basic simple precautions.

There is much current publicity over the risks to laboratory staff associated with handling specimens from patients infected with human immunodeficiency virus (HIV). Although standard tissue fixation methods inactivate most infectious agents, including HIV, they also render some antigens undetectable by immunocytochemistry and are unsuitable if cryostat sections are necessary.

Betapropiolactone (BPL) inactivates viruses in blood, serum, or plasma and enables them to be handled outside category 3 containment facilities. Some biochemical and haematological variables are affected by treatment with BPL, but far fewer than by heat inactivation or other sterilising procedures. ${ }^{1}$ BPL is relatively non-toxic, and can be safely handled in a fume cabinet but is carcinogenic in rats.

The effect of BPL on unfixed biopsy and necropsy tissues was investigated to establish if viruses were inactivated and if viral and tissue antigens were preserved.

The viral studies were performed on tissues from suckling mice infected with Coxsackie virus. This virus is resistant to routine disinfectants, including $70 \%$ alcohol and 5\% lysol and unaffected by $1 \%$ quarternary ammonium compounds or standard detergents which destroy other viruses including HIV. ${ }^{2}$

Accepted for publication 18 August 1988

\section{Material and methods}

Coxsackie virus type B5 was isolated from a human faecal specimen and stored at $-70^{\circ} \mathrm{C}$. Before inoculation into suckling mice the viability of the virus was confirmed by a single passage in Vero cells, grown in a standard cell culture medium.

A litter of six Balb/c mice, less than $\mathbf{4 8}$ hours old, was inoculated with $50 \mu \mathrm{l}$ of Coxsackie virus in cell culture fluid both intracerebrally and intraperitoneally. All the mice showed signs of infection after 48 hours, characterised by spastic paralysis. The animals were sacrificed, snap frozen, and stored at $-70^{\circ} \mathrm{C}$.

The animals were thawed, skinned, and divided in half longitudinally. One half of each animal was incubated in phosphate buffered saline (PBS), containing BPL (Sigma Chemical Co) to a final concentration of $0.25 \%(\mathrm{v} / \mathrm{v})$ for one hour at room temperature. The other half was treated similarly, with the omission of the BPL step. After treatment each half was further divided transversely. Serial cryostat sections were cut from one half. The other was finely minced in cell culture medium followed by clarifying centrifugation at $2000 \mathrm{rpm}$ for 10 minutes. The supernatants above were serially diluted in cell culture medium from $10^{-1}$ to $10^{-8}$ and $200 \mu \mathrm{l}$ aliquots inoculated on to Vero cells. The cells were examined daily for seven days for any cytopathic effect. 
DETECTION OF COXSACKIE VIRUS ANTIGENS

Cryostat sections of the mouse tissues were fixed in acetone at $20^{\circ} \mathrm{C}$ for 10 minutes, air dried, and reacted with $100 \mu$ l of rabbit polyclonal antibody to Coxsackie virus type B5 diluted 1/20 in PBS. After incubation at $37^{\circ} \mathrm{C}$ for 30 minutes the sections were washed in PBS for 10 minutes and reacted with $100 \mu \mathrm{l}$ of fluorescein labelled anti-rabbit serum diluted 1/20 in PBS. After incubation at $37^{\circ} \mathrm{C}$ for 30 minutes the sections were washed in PBS for 10 minutes and mounted in $90 \%$ glycerol before viewing under ultraviolet illumination.

\section{DETECTION OF COXSACKIE VIRUS SPECIFIC RNA}

In situ hybridisation for Coxsackie virus RNA was performed as previously described ${ }^{4}$ with the following modifications. The cryostat sections were fixed in Carnoy's fluid for five minutes at $20^{\circ} \mathrm{C}$, rehydrated through an ethanol series, and hybridised with heat denatured Coxsackie virus type B4 probe. This biotin labelled cDNA probe detects all the common picornaviruses. ${ }^{4}$ Hybridisation was shown using a streptavidin-alkaline phosphatase complex (Blu-gene, BRL) diluted $1 / 200$ in PBS, $5 \mathrm{mM}$ edetic acid, $0.5 \%$ Triton X-100, and $0.1 \%$ bovine serum albumin (BSA). After incubation at $20^{\circ} \mathrm{C}$ for 30 minutes the sections were given two 10 minute washes in $0.1 \mathrm{M}$ Tris $-\mathrm{HCl}$
(pH 7.5) and $0.15 \mathrm{M} \mathrm{NaCl}$ and then washed in $0.1 \mathrm{M}$ Tris- $\mathrm{HCl}(\mathrm{pH} \mathrm{9.5),} 0.1 \mathrm{M} \mathrm{NaCl}$ and $50 \mathrm{mM} \mathrm{MgCl}$ (buffer 1) for five minutes. Finally the sections were incubated in substrate $(2.5 \mathrm{ml}$ buffer $1,11 \mu 1$ nitroblue tetrazolium, 8.3 $\mu$ l 5-bromo-4-chloro-3-indolylphosphate) for 60 minutes. The reaction was stopped by washing with PBS, $0 \cdot 1 \%$ edetic acid.

\section{DETECTION OF NON-VIRAL ANTIGENS}

The effect of BPL on tissue antigenicity was assessed in two ways:

\section{Cryostat sections}

Cryostat sections $(6 \mu \mathrm{m})$ of normal tonsil and colon were cut, air-dried overnight, and then immersed in BPL in distilled water at room temperature. BPL was used at concentrations of $1 \%, 0.5 \%$, and $0.25 \%(v / v)$ and, for each concentration, sections were incubated for five, 15 , and 30 minutes and then washed in $0.05 \mathrm{M}$ (pH 7.6) Tris-buffered saline (TBS). Other sections were fixed for 10 minutes in acetone at room temperature before immersion in BPL at the same dilutions for 15 minutes. Control sections of tonsil and colon were fixed for 10 minutes in acetone at room temperature. All sections were immunostained using the alkaline phosphatase anti-alkaline phosphatase

Table 1 Series of antibodies used to detect tissue antigens

\begin{tabular}{|c|c|c|c|c|c|}
\hline \multirow[b]{2}{*}{ Antibody } & \multirow[b]{2}{*}{ Specificity } & \multicolumn{2}{|c|}{ Cryostat sections } & \multicolumn{2}{|c|}{ Tissue blocks } \\
\hline & & $B P L$ & No BPL & $B P L$ & No BPL \\
\hline 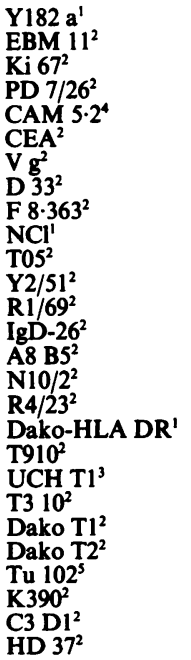 & $\begin{array}{l}\text { Monocytes/macrophages } \\
\text { Macrophages } \\
\text { Nuclear proliferation antigen } \\
\text { Leucocyte common antigen } \\
\text { Cytokeratin } \\
\text { Cytokeratin } \\
\text { Vimentin } \\
\text { Desmin } \\
\text { Factor VIII RA } \\
\text { Type IV collagen } \\
\text { C 3b receptor } \\
\text { Platelet glycoprotein IIIa } \\
\text { IgM } \\
\text { IgD } \\
\text { Kappa } \\
\text { Lambda } \\
\text { DRC } \\
\text { HLA-DR } \\
\text { CD } 2 \\
\text { CD } 3 \\
\text { CD } 4 \\
\text { CD } 5 \\
\text { CD } 7 \\
\text { CD } 8 \\
\text { CD 11 } \\
\text { CD } 15 \\
\text { CD } 19\end{array}$ & $\begin{array}{l}+ \\
+ \\
+ \\
+ \\
+ \\
+ \\
+ \\
+ \\
+ \\
+ \\
+ \\
+ \\
+ \\
+ \\
+ \\
+ \\
+ \\
+ \\
+ \\
+ \\
+ \\
+ \\
+ \\
+ \\
+ \\
+ \\
+\end{array}$ & $\begin{array}{l}+ \\
+ \\
+ \\
+ \\
+ \\
+ \\
+ \\
+ \\
+ \\
+ \\
+ \\
+ \\
+ \\
+ \\
+ \\
+ \\
+ \\
+ \\
+ \\
+ \\
+ \\
+ \\
+ \\
+ \\
+ \\
+ \\
+\end{array}$ & $\begin{array}{l}+ \\
+ \\
+ \\
+ \\
+ \\
+ \\
+ \\
+ \\
+ \\
+ \\
+ \\
+ \\
+ \\
+ \\
+ \\
+ \\
+ \\
+ \\
+ \\
+ \\
+ \\
+ \\
+ \\
+ \\
+ \\
+ \\
+ \\
+\end{array}$ & $\begin{array}{l}+ \\
+ \\
+ \\
+ \\
+ \\
+ \\
+ \\
+ \\
+ \\
+ \\
+ \\
+ \\
+ \\
+ \\
+ \\
+ \\
+ \\
+ \\
+ \\
+ \\
+ \\
+ \\
+ \\
+ \\
+ \\
+ \\
+ \\
+ \\
+ \\
+\end{array}$ \\
\hline
\end{tabular}

Sources of antibodies:

'DY Mason

${ }^{2}$ Dakopatts

${ }^{3}$ Seward

${ }^{4}$ Becton Dickinson

${ }^{5}$ Clonab 
(APAAP) technique with a series of antibodies (table 1).

\section{Fresh tissue blocks}

Tissue blocks $(8 \times 6 \times 6 \mathrm{~mm})$ of normal spleen and colon were immersed for 30 minutes in $0.5 \%$ BPL in distilled water at room temperature. The tissues were then washed in either physiological saline, TBS, or Dextran before being frozen in liquid nitrogen. As a control a block was immediately snap frozen without any pretreatment.

Cryostat sections $(6 \mu \mathrm{m})$ were cut from all blocks and fixed for 10 minutes in acetone. These were stained, firstly with a conventional haematoxylin and eosin stain to assess morphological preservation, and secondly by the APAAP technique using the series of antibodies listed in table 1.

\section{Results}

The virus titre in the untreated tissue was at least $10^{6}$ $\mathrm{pfu} / \mathrm{ml}$ and in the BPL treated tissue the infectivity was reduced, with one exception, by a minimum of 4 logs (table 2).

As judged by intensity of fluorescence, the BPL treatment did not destroy virus antigens or alter their intracellular distribution.

No major differences were evident between the intensities of the precipitates produced or in the histological distribution of the hybridisation.

In all instances the tissue antigens studied remained detectable after exposure to BPL (table 1, figure). The quality of the demonstration was improved when the sections had been fixed in acetone. The tissue morphology was satisfactory in all experiments and not adversely affected by the duration of the exposure or the concentration of the BPL solution. Blocks of tissue pre-treated with BPL were easily sectioned and presented no technical difficulties.

Table 2 Infectivity of tissue samples with and without BPL treatment

\begin{tabular}{lll}
\hline & Treated tissue* $^{*}$ & Untreated tissue* \\
\hline $\begin{array}{l}\text { Experiment A: } \\
\text { Mouse 1 }\end{array}$ & $<10^{1}$ & $>10^{-6}$ \\
Mouse 2 & $1 \times 10^{-2}$ & $>10^{-6}$ \\
$\begin{array}{l}\text { Experiment B: } \\
\text { Mouse 3 }\end{array}$ & $>10^{-3}$ & $>10^{-8}$ \\
Mouse 4 & $2 \times 10^{-3}$ & $>10^{-8}$ \\
Mouse 5 & $1 \times 10^{-3}$ & $1 \times 10^{-7}$ \\
Mouse 6 & $1 \times 10^{-3}$ & $>10^{-8}$ \\
\hline
\end{tabular}

*Greatest virus dilution producing cytopathic effect.

Experiment $\mathbf{A}$ and experiment $\mathbf{B}$ represent virus titrations done on different occasions.

\section{Discussion}

These series of experiments show that BPL can inactivate Coxsackie virus infectivity in tissues without affecting its antigenicity. They also show that BPL does not affect the antigenicity of some tissue antigens. The results are in keeping with similar observations on immunological variables in serum samples as well as with the use of this substance in the preparation of rabies vaccine and the sterilisation of blood and serum samples for haematological and biochemical testing. ${ }^{56}$

Coxsackie virus is extremely resistant to all standard disinfecting procedures and the great reduction in its infectivity by BPL is firm evidence of the effectiveness of this substance in this connection. Other viruses, including HIV, are more easily inactivated and it is therefore fair to conclude that following exposure of tissues to BPL any infectivity from these would be greatly reduced, if not totally eradicated. The application of this method to tissues from HIV positive patients, where studies on fresh, unfixed material are necessary, is clearly evident, although not unequivocally proved, as HIV positive tissues were not studied. Others have, however, shown that BPL does inactivate HIV in aqueous medium, serum, and plasma. ${ }^{6}$

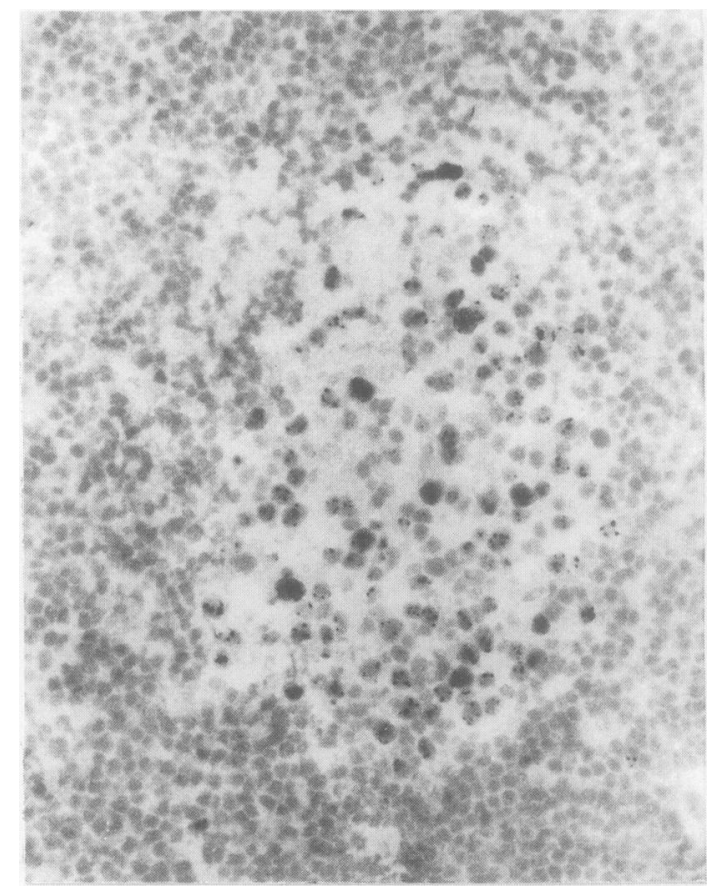

Figure Cryostat section of splenic tissue immersed in $B P L$ and exposed to Ki 67 using APAAP technique. This antibody is difficult to use and clear positivity shows that BPL has had no harmful effect on antigen expression. 
Unfixed tissues are used either for rapid diagnosis or for immunohistochemical studies. Our investigations show that BPL does not impair morphological appearances or affect the antigenicity of common tissue antigens as well as those to the Coxsackie virus. Although we did not test the effect of BPL on all known tissue antigens, those studied usually reflect the antigenicity of other common tissue antigens and it is suggested that few, if any, tissue antigens will be adversely affected by BPL. A similar argument is proposed for viral antigens as those in tissues have, to date, shared common sensitivities to routine fixatives. A possible limitation of the method is the carcinogenicity of BPL. Tumours have occurred in rodents but only at moderate and high doses. ${ }^{78}$ Similar observations have not been made in man and any risk can be reduced by wearing disposable gloves and restricting the substance to extraction cabinets. The end products of the hydrolysis of BPL produced by plasma and serum are not carcinogenic.

In conclusion, exposure of the tissues to BPL is a safe and effective means of inactivating any common viruses and one that is highly appropriate to tissues from patients harbouring or potentially exposed to
HIV. There is no evidence that the antigenicity of any tissue component is adversely affected.

\section{References}

1 Ball MJ, Griffiths D. Beta-propiolactone treatment of whole blood and plasma. Lancet 1985; i: 1160.

2 Brown F, Wilson G. Principles of bacteriology, virology and immunity. Vol 4. London: Edward Arnold Ltd, 1984:407.

3 Horsfall FL, Tamm I. Viral and rickettsial infections of man. Lippincott Ltd, 1965:477.

4 Easton AJ, Eglin RP. The detection of Coxsackie virus RNA in cardiac tissue by in situ hybridisation. J Gen Virol 1988;69: 285-91.

5 Freeman R, Codd AA, Selkon JB. Effect of Beta-propiolactone in blood on routine haematological, biochemical and serological investigations. Lancet 1982;i:1048-9.

6 Ball MJ, Spriggs V, Sutton PM, Chapel H. Effect of B-propiolactone-an inhibitor of HTLVIII/LAV activity- on immunological analyses. J Immunol Methods 1986;95:113-6.

7 Montesano R, Bartsch H, Vainio H, Wilbourn J, Yamasaki H. Long-term and short-term assays for cahcinogens: a critical appraisal. IRAC 1986;83:105.

8 Dickens F. Carcinogenic lactones and related substances. $\mathrm{Br}$ Med Bull 1964;20:96-101.

Requests for reprints to: Dr P R Millard, EM Unit, Level 1, John Radcliffe Hospital, Oxford OX3 9DU, England. 